\title{
Drift algae, an invasive snail and elevated temperature reduce ecological performance of a warm-temperate seagrass, through additive effects
}

\author{
Hannes Höffle ${ }^{1}$, Thomas Wernberg ${ }^{2,3,4, *}$, Mads S. Thomsen ${ }^{2,4}$, Marianne Holmer $^{1}$ \\ ${ }^{1}$ Institute of Biology, University of Southern Denmark, Campusvej 55, 5230 Odense M, Denmark \\ ${ }^{2}$ UWA Oceans Institute \& School of Plant Biology, University of Western Australia, 35 Stirling Highway, Nedlands, \\ 6009 Western Australia, Australia \\ ${ }^{3}$ Australian Institute of Marine Science, 39 Fairway, Nedlands, 6009 Western Australia, Australia \\ ${ }^{4}$ Centre for Marine Ecosystems Research, Edith Cowan University, 270 Joondalup Drive, Joondalup, 6017 Western Australia, Australia
}

\begin{abstract}
Seagrasses are under pressure from multiple concurrent threats, including rising temperatures, invasive species and nutrient-driven algal accumulations. We quantified the abundance of drift algae and the invasive snail Batillaria australis in 3 Halophila ovalis seagrass beds in the Swan River Estuary (Perth, Western Australia), and tested in an aquarium experiment for interactive effects of temperature $\left(21 \mathrm{vs} .27^{\circ} \mathrm{C}\right)$, cover of drift algae Chaetomorpha linum (0 vs. $1.4 \mathrm{~kg}$ fresh wt $\mathrm{m}^{-2}$ ) and presence ( 0 vs. 120 snails $\left.\mathrm{m}^{-2}\right)$ of $B$. australis on the ecological performance of $H$. ovalis. The survey showed that drift algae varied considerably between sites and sampling times, and sites experienced average loads of 0.4 to $0.8 \mathrm{~kg}$ fresh $\mathrm{wt} \mathrm{m}^{-2}$ and extreme loads up to $2.5 \mathrm{~kg}$ fresh wt $\mathrm{m}^{-2}$. In contrast, invasive snails were constantly abundant at all sites at all collection times (mean abundance: 489 snails $\mathrm{m}^{-2}$ ). In the laboratory experiment, drift algae caused increased shoot mortality and leaf loss rate, and suppressed the formation of new nodes. Drift algae also decreased the depth of the sulphide horizon in the sediment and the oxygen concentration in the water column at night, suggesting increased risk of hypoxia. Invasive snails reduced the biomass of $H$. ovalis leaves and roots, increased leaf plastochrone interval and decreased the depth of the sulphide horizon. Finally, elevated temperature increased leaf loss and reduced leaf biomass, and, in the presence of drift algae, also reduced the length of the 2nd internode. We found relatively few significant higher-order interactions, suggesting a dominance of additive effects of stress. We conclude that temperature, drift algae and invasive snails are already affecting the ecological performance of $H$. ovalis in Swan River, and that these seagrass beds are likely to come under further pressure if these stressors increase in the future.
\end{abstract}

KEY WORDS: Global warming · Eutrophication · Introduced species · Swan River · Western Australia $\cdot$ Halophila ovalis $\cdot$ Batillaria australis

\section{INTRODUCTION}

Estuaries are focal points for human activities and extraction of resources, and are therefore among the most seriously impacted and threatened coastal ecosystems in the world (Lotze et al. 2006). Seagrass beds provide a number of ecosystem services that are critical to the ecological function of estuaries, including habitat for invertebrates, fish and birds, and stabilisation of sediments. On a global scale, $>65 \%$ of the world's seagrass beds have been lost (Lotze et al. 2006), and seagrasses continue to be under pressure from multiple concurrent stressors, of which indirect effects associated with eutrophication (in particular, competition with drift algae, epiphytes or phytoplankton), global warming and invasive species are considered among the worst (Orth et al. 2006).

Eutrophication reduces the competitive advantage that seagrasses have over algae at low nutrient concentrations in the water column (seagrasses can take 
up nutrients from sediment pore water through their roots) and is therefore a serious threat to coastal environments and seagrasses worldwide (Nielsen et al. 2002). Algae, and drift algae such as the cosmopolitan Chaetomorpha linum (Müller) Kützing in particular, benefit from higher nutrient loads because they typically have finely structured thalli with a high capacity for nutrient uptake and growth (Hauxwell et al. 2003). Drift algae often form dense mats that can become entangled and retained among the seagrasses, especially in areas of low hydrodynamic activity (Irlandi et al. 2004). These algal mats can block out light from the seagrasses and cause hypoxia through respiratory processes, particularly at night. Moreover, drift algae have a boom-and-bust life cycle, supplying rapidly decomposing organic material to the sediment (Pedersen et al. 2005), which increases the oxygen consumption in the sediment.

Rapid climate change is a relatively recent threat to seagrasses. Elevated levels of atmospheric $\mathrm{CO}_{2}$ are causing a range of changes to the environment that are likely to impact seagrasses, including ocean acidification, rising sea levels and increasing temperature (Short \& Neckles 1999, Lotze et al. 2006, Orth et al. 2006, Williams 2007). Global warming is probably the most acute of the climate-change-related threats. For example, over the past 5 decades, the temperature in the southeast Indian Ocean adjacent to Western Australia has been rising at a rate of up to $0.02{ }^{\circ} \mathrm{C}$ $\mathrm{yr}^{-1}$ (Pearce \& Feng 2007), and the projection for the region is an additional 1 to $2^{\circ} \mathrm{C}$ increase in mean temperature over the next 25 yr (Poloczanska et al. 2007). Elevated temperature directly influences metabolic processes in plants, increasing the rates of photosynthesis and respiration and affecting the ratio between them (Stæhr \& Wernberg 2009). Temperate seagrasses typically have their photosynthetic optimum at temperatures below the seasonal maximum (Biebl \& McRoy 1971) and may therefore be sensitive to elevated temperatures. The effects may be severe enough to cause oxygen depletion in seagrass tissue (Greve et al. 2003).

Elevated temperature and eutrophication interact synergistically to increase bacterial metabolism in the sediment, usually by a factor of 2 to 3 for each $10^{\circ} \mathrm{C}$ increment (Thamdrup et al. 1998), thereby stimulating oxygen consumption in the sediments and accumulation of sulphide in the sediment pore water. Sulphide can bind to the iron in metalloenzymes and is therefore a potent phytotoxin that inhibits important enzymes like cytochrome oxidase (Raven \& Scrimgeour 1997, Armstrong \& Armstrong 2005). Negative effects of pore water sulphide and high oxygen demand leading to plant anoxia have been documented for several seagrass species (Holmer \& Bondgaard 2001, Greve et al. 2003, Koch et al. 2007, Kilminster et al. 2008). Plants alleviate anoxia by transporting oxygen to the belowground parts, where it is released to the surroundings, creating an oxygenated rhizosphere that prevents the intrusion of reduced compounds (Frederiksen \& Glud 2006). This oxygen is produced by photosynthesis during the day and taken up from the surrounding water column at night, as the oxygen in the lacunae only lasts for minutes when photosynthesis stops at night (e.g. Sand-Jensen et al. 2005). If the oxygen concentration in the water column drops below a certain percentage of air saturation (e.g. 35\% for Zostera marina), then oxygen is depleted in the plants and pore water sulphide can intrude into the seagrass (Pedersen et al. 2004).

In addition to global warming and competition with drift-algal accumulations, invasions by introduced species present yet another possible stressor of seagrass beds. Increasing ocean traffic and reduced transit times of vessels between harbours have caused a massive increase in the exchange of marine species among distant areas of the globe (Williams \& Smith 2007, Thomsen et al. 2011). Introduced species can have a range of effects in their recipient systems, including predating on or competing with native species (Thomsen et al. 2009) or changing nutrient cycles (Pedersen et al. 2005). Effects of introduced species tend to be particularly large in estuaries because these are typical end-points for dispersal vectors and because estuaries are often stressed systems (either naturally or from human activities) where new opportunistic species can readily establish themselves.

The city of Perth (population approximately 1 million) is the only metropolitan area in Western Australia, and it is located on the banks of the SwanCanning Estuary (hereinafter referred to as Swan River), which has had a history of intense human activity since the early colonisation of Australia (Brearley 2005). The dominant benthic primary producer in the Swan River is the seagrass Halophila ovalis (Hillman et al. 1995). H. ovalis stands cover approximately $25 \%$ of the total estuarine basin, with most of the population in protected waters $<2 \mathrm{~m}$ deep, where drift algae also tend to accumulate (Astill \& Lavery 2001). The invasive mud snail Batillaria australis has established itself in the Swan River within the past $50 \mathrm{yr}$, and it is now highly abundant within the $H$. ovalis beds $\left(>400 \mathrm{~m}^{-2}\right.$; Thomsen et al. 2010). B. australis does not graze on the seagrass, but 
feeds primarily on benthic diatoms and detritus. However, the abundance and burying behaviour of $B$. australis causes significant bioturbation. This may affect seagrasses directly through uprooting or indirectly by modifying the concentration of organic matter and reduced compounds in the sediments (i.e. by burial of drift algae in the sediments or by increasing advection). These potential effects could hamper the formation of new seagrass meadows after a die-back event, such as the one that occurred in winter 1981, which was caused by unusually high river discharge (Hillman et al. 1995). As B. australis does not build ventilated structures, like for example certain polychaetes (Pischedda et al. 2008), its effect on oxygen uptake of the sediment may be comparatively low. The aim of the present study was to examine the impact of drift algae on seagrasses, and to assess the role of an invasive species in mediating these effects now and in a warmer future. To address this aim, we quantified the abundance of drift algae and invasive snails in the Swan River, and we experimentally tested the hypothesis that at least 2 factors would interact synergistically to exacerbate negative effects of drift Chaetomorpha linum on sediment biogeochemical properties and growth and survival of $H$. ovalis.

\section{MATERIALS AND METHODS}

\section{Spatio-temporal variability of drift algae, invasive snails and temperature in Swan River}

The abundances of drift algae and invasive snails were quantified in 3 seagrass beds at 0.5 to $2 \mathrm{~m}$ depth in the Swan River (Freshwater Bay, Point Walter and Waylen Bay; Fig. 1). Drift algae were quantified on 5 occasions from May 2008 to February 2009, by collecting all algae within 10 haphazardly tossed $0.25 \mathrm{~m}^{2}$ quadrats. The algae were returned to the laboratory and weighed fresh after blotting with paper towels, consistently using the same materials to reach the same degree of dryness. Snails were counted within 4 random circular frames $(0.33 \mathrm{~m}$ diameter) in May 2006, November 2007 (no data from Point Walter) and December 2008. To test whether the abundance of both stressors was constant or variable in space and time, algal and snail data were analysed by 2-way ANOVA (PRIMER v. 6; Clarke \& Gorley 2006), where sites and sampling times were considered random factors.

Temperature was measured at 3 sites (Point Roe, Point Resolution and South Como; Fig. 1) from 17

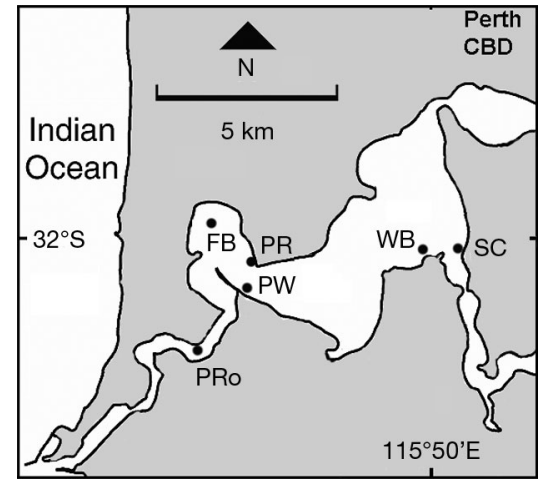

Fig. 1. Swan River, Western Australia, showing the 3 sites where drift algae and snails were sampled (FB: Freshwater Bay; PW: Point Walter; WB: Waylen Bay), where temperature was measured (PRo: Point Roe; PR: Point Resolution; SC: South Como) and where seagrasses were collected for the experiment (PR). CBD: central business district

May 2008 to 10 February 2009. Temperature was recorded $\sim 10 \mathrm{~cm}$ above the bottom at $1 \mathrm{~m}$ depth every $30 \mathrm{~min}$ with Hobo data loggers. Data from Point Roe between May and July were missing due to the loss of a data logger. Temperatures were tested for differences between sites by paired $t$-tests between daily mean temperatures (GMAV 5; Sage 2002).

\section{Laboratory experiment}

\section{Setup}

The individual and combined effects on seagrass performance of temperature $\left(21\right.$ and $\left.27^{\circ} \mathrm{C}\right)$, drift algae ( 0 and $\sim 1.4 \mathrm{~kg}$ fresh wt Chaetomorpha linum $\mathrm{m}^{-2}$ ) and an invasive species $(0$ and $\sim 120$ Batillaria australis ind. $\mathrm{m}^{-2}$ ) were tested in a 3 -factorial aquarium experiment with 3 replicates of all orthogonal treatment combinations. The experimental treatment levels were all in the low range of extreme values recorded in situ to provide conservative tests of possible field effects (see Fig. 2). The aquaria were filled with $\sim 5 \mathrm{~cm}$ quartz sand (average grain size: $458 \mu \mathrm{m}$ ) and $\sim 25 \mathrm{l}$ seawater. About one-third of the water was exchanged each week, and air stones aerated the water column and provided gentle water circulation. Standard aquarium heaters were used to achieve the higher temperature $\left(27.4 \pm 0.2^{\circ} \mathrm{C}, \mathrm{n}=7\right.$ aquaria; daily means from loggers recording every $20 \mathrm{~min}$ ), whereas the lower temperature $\left(21.4 \pm 0.1^{\circ} \mathrm{C}, \mathrm{n}=6\right.$ aquaria $)$ was ambient temperature in the aquarium room. Light was provided by 2 daylight fluorescent tubes and 2 UV-tubes in a $12 \mathrm{~h}$ light: $12 \mathrm{~h}$ dark cycle. 
Halophila ovalis shoots were collected from Point Resolution (Fig. 1), and Chaetomorpha linum was collected from several sites around the Swan River. The seagrasses were trimmed to a rhizome apical meristem plus 2 internodes with a leaf-pair each (this standardised planting unit is hereafter referred to as a 'shoot') and planted in 2 rows of 4 into each aquarium ( 239 leaf pairs $\mathrm{m}^{-2}$ and $\sim 119$ rhizome growth apices $\mathrm{m}^{-2}$ ). This density is relatively low, but nevertheless often occurs in winter and spring months (<300 growth apices $\mathrm{m}^{-2}$; Hillman et al. 1995) and at the margins of Halophila beds (authors' pers. obs.). The younger leaf pair was clipped (i.e. had a corner cut out of one leaf) to mark the beginning of new shoot production. Each planting unit was photographed on a sheet of white paper, and the length of both leaf pairs, internodes, the apical meristem (measured from the tip to the first node) and the first root was measured. Terminology and definitions of seagrass characteristics and measurements follow Duarte et al. (1994). Occasionally the bulldozing snails uprooted seagrass shoots and these were subsequently found drifting. At the margin of real seagrass beds, such uprooted growth apices are typically attached to a longer rhizome and may therefore re-attach to the sediment. We therefore decided to replant uprooted units in our aquaria.

Seagrasses were acclimatised for 2 to $3 \mathrm{~d}$. The aquaria for the high temperature treatment were warmed up over this time and drift algae were added to half of all aquaria thereafter. The algae were first examined in terms of sight, smell and texture and were discarded if of questionable quality. The rest was cleaned of other algal species and animals, and weighed after blotting with paper tissue. Drift algae were replaced twice to avoid decomposition of the mat and ensure constant biomass levels between aquaria with drift algae, and the average drift-algal biomass over the duration of the experiment was $1.5 \pm 2 \mathrm{~kg}$ fresh wt $\mathrm{m}^{-2}(\mathrm{n}=12)$. Eight snails were added to half of the aquaria at the same time as the algae. Snails, drift algae and seagrass appeared to acclimatise quickly to the 2 temperature levels, as seagrass grew without other stressors, drift algae generally remained healthy and intact, and snails moved around and created burial trails. The experiment ran for $28 \mathrm{~d}$, a common stressduration for drift-algal studies. This duration is in accord with the typical persistence of algal patches in seagrass beds (Thomsen 2010) and was well above previously reported plastochrone intervals (2.2 d for shoots and leaves, $3.3 \mathrm{~d}$ for rhizomes; Short \& Duarte 2001).

\section{Growth measurements}

Upon harvest, the number of surviving shoots was counted and the mortality rate calculated as percentage loss of growth apices per day:

$$
\text { mortality rate }=\frac{n_{D}}{n_{0}} / t
$$

where $n_{\mathrm{D}}$ and $n_{0}$ were the numbers of dead growth apices and growth apices at the beginning of the experiment respectively and $t$ was the duration of the experiment (days). A growth apex and the whole shoot with it was classified as dead if the apical meristem showed signs of decay and disintegration.

The number of new nodes produced during the experiment was counted, and the leaf loss rate calculated as percentage of leaves lost per day (relative to the sum of leaves at the beginning and leaves produced). Pre-planting measurements were repeated and plastochrone interval of leaves (time in days to grow a new leaf) and net change in leaf length were calculated using the formulas:

$$
\begin{gathered}
P_{L}=\frac{t}{n_{L}} \\
\text { Net change of leaf }=\frac{\sum 1_{\text {start }}-\sum 1_{\text {end }}}{t}
\end{gathered}
$$

where $P_{\mathrm{L}}$ was the plastochrone interval (days), $n_{\mathrm{L}}$ was the number of leaves produced during the experiment, $t$ was the duration of the experiment (days), and $\Sigma l_{\text {start }}$ and $\Sigma l_{\text {end }}$ were the accumulated lengths of all leaves on the shoot $(\mathrm{mm})$. Net change in leaf length was expressed in $\mathrm{mm}$ per day. The length of the 2 nd internode was measured as the distance from 1 st to 2 nd node, as seen from the direction of the apex, as we considered it less exposed than the 1st internode. Biomass was measured separately for leaves, rhizomes and roots, and reported as the mean dry weight per surviving shoot per aquarium.

Effects on each univariate variable were tested by 3-way fixed-factor ANOVA using GMAV 5 (Sage 2002), with temperature, snails and algae as fixed factors. Prior to analysis, each variable was checked for homogeneity of variances by Cochran's $C$-test and transformed if variances were heteroscedastic. Transformation solved all problems of heterogeneous variances. Post hoc analyses of significant interactions were done by Student-Newman-Keuls (SNK) tests $(\alpha=0.05)$. Taking all response variables into account, and following the same experimental design, multivariate analysis of variance by permutation (PERMANOVA; PRIMER v. 6; Clarke \& Gorley 
2006) was used to test for experimental effects on overall seagrass performance. These multivariate analyses were based on Euclidian distances calculated from normalised data.

\section{Sediment and oxygen analyses}

The depth to the sulphide horizon in the sediment was measured 3 times during the experiment. At each time, one silver stick (1.2 mm thick thread of $99 \%$ Ag) was haphazardly placed in each aquarium and incubated for $6 \mathrm{~h}$ (Holmer et al. 2005). The depth to the sulphide horizon was measured with a ruler as the distance from the sediment surface to the black coating of $\mathrm{Ag}_{2} \mathrm{~S}$. The data was analysed with a 4-way ANOVA where time was considered a random factor and the 3 experimental treatments fixed factors.

The organic content of the sediment was measured by loss on ignition at $560^{\circ} \mathrm{C}$ for $6 \mathrm{~h}$. Chlorophyll a (chl a) content was extracted from the top centimetre of the sediment, using $3.5 \mathrm{ml}$ ethanol, and quantified photometrically at $665 \mathrm{~nm}$. The results were analysed by 3-way fixed-factor ANOVA.

Measurement of oxygen content in the water column was done every week before exchanging the water. Measurements were done with a handheld dissolved oxygen (DO) meter (Oxyguard) and within the last $2 \mathrm{~h}$ of each period of the diurnal cycle (i.e. day and night). The oxygen content was measured in the upper water column ca. $20 \mathrm{~cm}$ above sediment surface (= ca. $5 \mathrm{~cm}$ above the drift-algal mat), ca. $10 \mathrm{~cm}$ above the sediment surface in the centre of the drift-algal mat (= mid-water) and $<1 \mathrm{~cm}$ from the sediment surface (= bottom, below the drift mat). The weekly measurements at the sediment surface were averaged for each aquarium, and treatment effects on oxygen levels analysed with a 5-way fixed-factor ANOVA. Pearson's product moment correlation tested the relationship between mean oxygen concentration at the bottom at night, where the lowest oxygen levels were recorded, and seagrass mortality rate.

\section{RESULTS}

\section{In situ patterns of drift algae, invasive snails and temperature}

Four taxa accounted for $>90 \%$ of the drift-algal biomass: across sites and times, the green alga Chaetomorpha linum ( 40\%) was dominant, fol- lowed by the red algae Gracilaria comosa ( 25\%), Hypnea sp. $(\sim 15 \%)$, and Laurencia sp. $(\sim 10 \%)$. The abundance of drift algae was highly variable from site to site and between sampling times (Fig. 2A; $\mathrm{p}_{\text {site } \times \text { time }}<0.0001$; Table $\mathrm{S} 1$ in the supplement at www.int-res.com/articles/suppl/m450p067_supp. pdf). Winter (July) and early spring (September) were times of low drift-algal abundance at all sites, the maximum amount collected in any quadrat being $316.8 \mathrm{~g}$ fresh wt $\mathrm{m}^{-2}$. High drift-algal abundances were found in summer (December, February) and autumn (May) but peak abundances were found at different times at different sites. Average peak abundance ranged from $\sim 400$ to $800 \mathrm{~g}$ fresh $\mathrm{wt} \mathrm{m}^{-2}$. All sites also experienced times of very low drift-algal abundance $\left(<74.8 \mathrm{~g}\right.$ fresh $\left.\mathrm{wt} \mathrm{m}^{-2}\right)$ even when abundance peaked at other sites. Drift abundance also varied greatly from quadrat to quadrat as indicated by the highly heteroscedastic variances even after transformation-all sites and times had quadrats with and without drift algae, and extreme values were often 2 to 3 orders of magnitude greater than the means, reaching up to $2526 \mathrm{~g}$ fresh $\mathrm{wt} \mathrm{m}^{-2}$.

In contrast to drift algae, the abundance of Batillaria australis did not vary significantly between sites or sampling times $(\mathrm{p}>0.06)$. Indeed, snails were abundant in all samples, ranging from 47 to 1181 snails $\mathrm{m}^{-2}$, with an overall mean among sites of $489 \pm$ 70 snails $\mathrm{m}^{-2}(\mathrm{n}=8)$ (Fig. $\left.2 \mathrm{~B}\right)$.

Water temperature showed a clear seasonal development (Fig. 2C) with a late winter minimum in JulyAugust (lowest value recorded: $12.3^{\circ} \mathrm{C}$ ) and a summer maximum around January (highest value recorded: $31.2^{\circ} \mathrm{C}$ ) after which temperatures started to decline again. Water temperatures were $>25^{\circ} \mathrm{C}$ for most of December and January at all 3 sites, but on average, temperatures were higher further into the estuary (South Como $>$ Point Resolution $>$ Point Roe; $t>2.12, \mathrm{p}<0.035)$.

\section{Laboratory experiment}

Seagrass mortality and performance

The aquarium experiment showed that temperature and drift algae both increased the mortality of apical meristems and leaf loss of Halophila ovalis shoots (Fig. 3; Table S2 in the supplement). However, whereas effects of drift algae $(p=0.001)$ and temperature $(\mathrm{p}=0.005)$ on leaf loss were straightforward, increasing the leaf loss rate from $\sim 2$ to $\sim 3 \% \mathrm{~d}^{-1}$, the effects on mortality were interactive $(p=0.049)$. At 

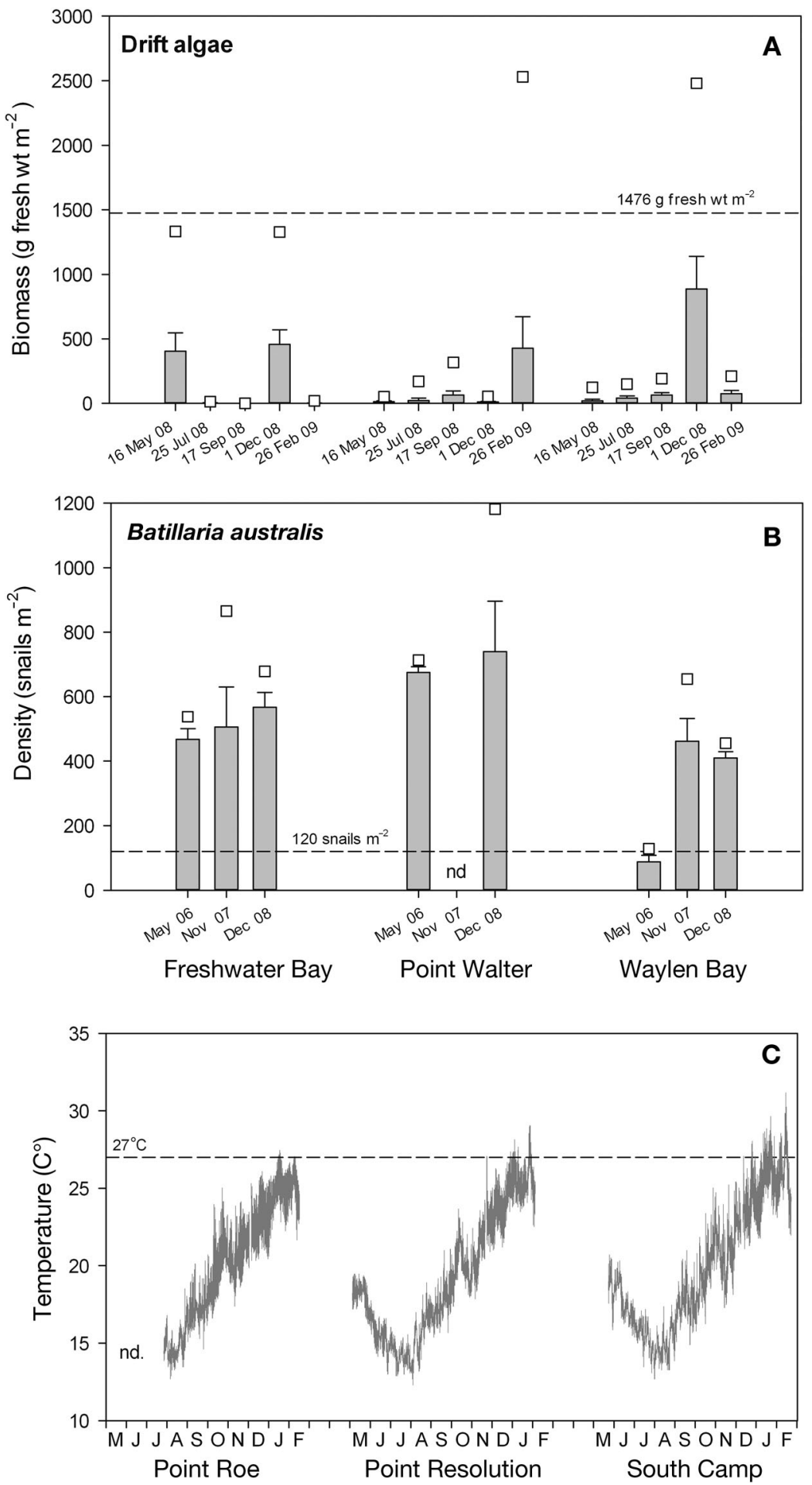

Fig. 2. In situ patterns of (A) biomass of drift algae, (B) densities of invasive snails Batillaria australis and (C) water temperature at 3 sites in the Swan River. Note that (C) shows different sites than (A) and (B). Bars are mean values $( \pm \mathrm{SE})(\mathrm{n}=10$ for drift algae, $n=4$ for snails) and white squares are maximum values recorded in any one sample. The dashed lines indicate levels used in the aquarium experiment. nd: no data low temperature $\left(21^{\circ} \mathrm{C}\right)$ without drift algae, mortality was $<0.5 \%$ growth apices $\mathrm{d}^{-1}$, but this increased 4 -fold to $\sim 2 \%$ growth apices $\mathrm{d}^{-1}$ when covered by drift algae at both low and high $\left(27^{\circ} \mathrm{C}\right)$ temperature and at high temperature regardless of drift algae. The presence of snails did not affect the mortality rate $(p=0.620)$ or the leaf loss rate $(p=0.774)$.

Drift algae caused $\sim 50 \%$ reduction in the production of new leaf pairs ( $p=$ $0.010)$, but neither temperature ( $p=0.829)$ nor snails ( $p=0.919$ ) had any effect on production of new leaf pairs (Fig. 4A,B, Table S2). In contrast, the plastochrone interval was affected by all 3 experimental factors (Fig. 4C,D, Table S2). Temperature had a consistent effect across drift algae and snail treatments $(p=0.026)$, with slightly lower plastochrone interval at $27^{\circ} \mathrm{C}$ compared to $21^{\circ} \mathrm{C}$ (Fig. 4C,D). Effects of algae and snails were interactive $(\mathrm{p}=0.038)$, where snails increased the plastochrone interval in the presence of drift algae but had no effect when algae were absent.

Net change in leaf length was typically negative due to the shedding of leaves (Fig. S1 in the supplement). The experimental treatments did not have any significant effects on this rate (Table S2). However, there was a trend for snails to negatively affect net change in leaf length $(p=0.08)$, with rates being 3 times lower in treatments with snails $(-1.32 \pm 0.32 \mathrm{~mm}$ $\left.\mathrm{d}^{-1}\right)$ compared to treatments without snails $\left(-0.43 \pm 0.15 \mathrm{~mm} \mathrm{~d}^{-1}\right)$.

The distance between internodes was affected by an interaction between temperature and algae $(\mathrm{p}=0.048)$, where drift algae reduced the length of the 2 nd internode by almost $50 \%$ at $27^{\circ} \mathrm{C}$ but had no effect at $21^{\circ} \mathrm{C}$ (Fig. $4 \mathrm{E}, \mathrm{F}$, Table S2). The biomass per shoot was affected by temperature and snails, but the effects differed between different biomass components (Fig. 5). Both elevated temperature $(\mathrm{p}=$ 0.039 ) and the presence of snails ( $p=$ 0.014 ) reduced the above-ground biomass per shoots. Snails also had a negative effect on the root biomass per shoots $(p=$ 0.017), but rhizome biomass per shoot was not significantly affected by any of the 

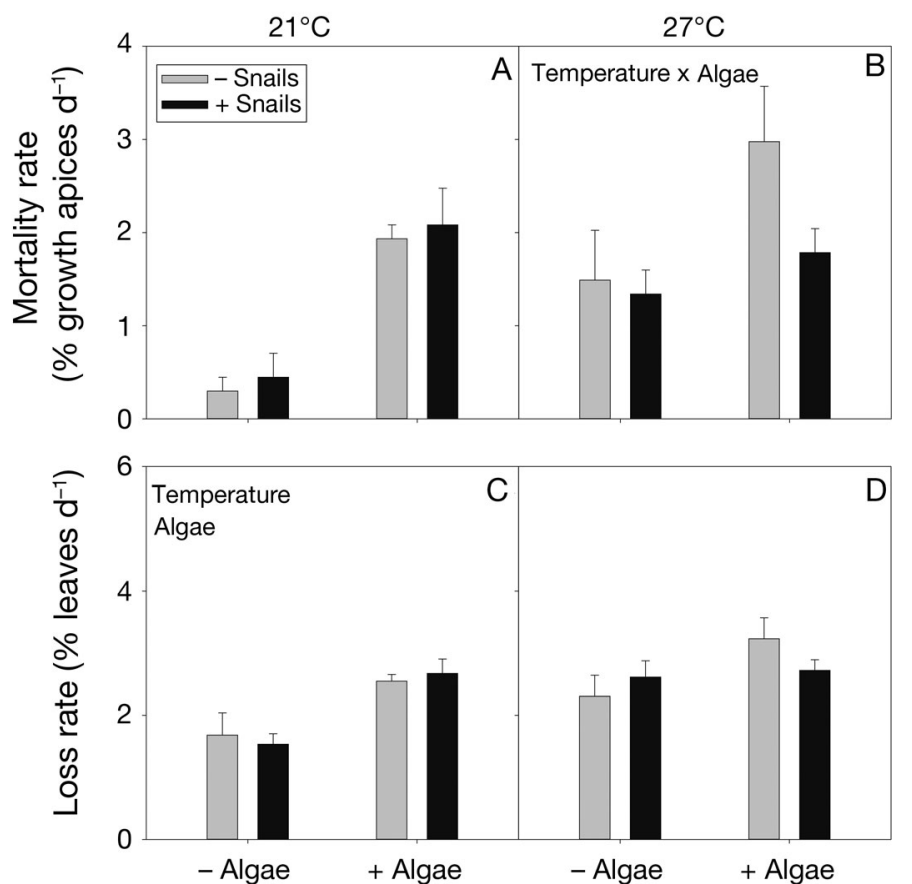

Fig. 3. Halophila ovalis. $(\mathrm{A}, \mathrm{B})$ Mortality rate and $(\mathrm{C}, \mathrm{D})$ leaf loss rate (mean $\pm \mathrm{SE}$ ) for shoots in aquaria with or without algae Chaetomorpha linum and snails Batillaria australis at $(\mathrm{A}, \mathrm{C}) 21^{\circ} \mathrm{C}$ and $(\mathrm{B}, \mathrm{D}) 27^{\circ} \mathrm{C}$. The factors or interactions named in the graph are those that caused significant differences

experimental test factors $(p>0.1)$. Still, there was a trend for snails to reduce rhizome biomass per shoot at high temperature (Fig. 5C,D).

Considering all response variables simultaneously in a single multivariate analysis of impacts on ecological performance, it was found that drift algae $(\mathrm{p}<$ $0.013)$ and snails $(p<0.038)$ were the only 2 factors to cause significant effects (Table 1). Drift algae was the most influential factor, contributing more than twice as much to variation $(16.1 \%)$ than any of the other experimental factors or their interactions $(8.3 \%)$. Neither temperature nor any interactions with it were significant, although the effect of temperature was close to significant $(p=0.076)$.

\section{Abiotic responses}

Both drift algae $(p<0.0001)$ and snails $(p=0.014)$ reduced the depth of the sulphide horizon, such that the oxygenated zone was $>4$ times deeper in aquaria without algae and snails compared to aquaria with both algae and snails (Fig. 6). Depth to the sulphide horizon was not significantly affected by temperature
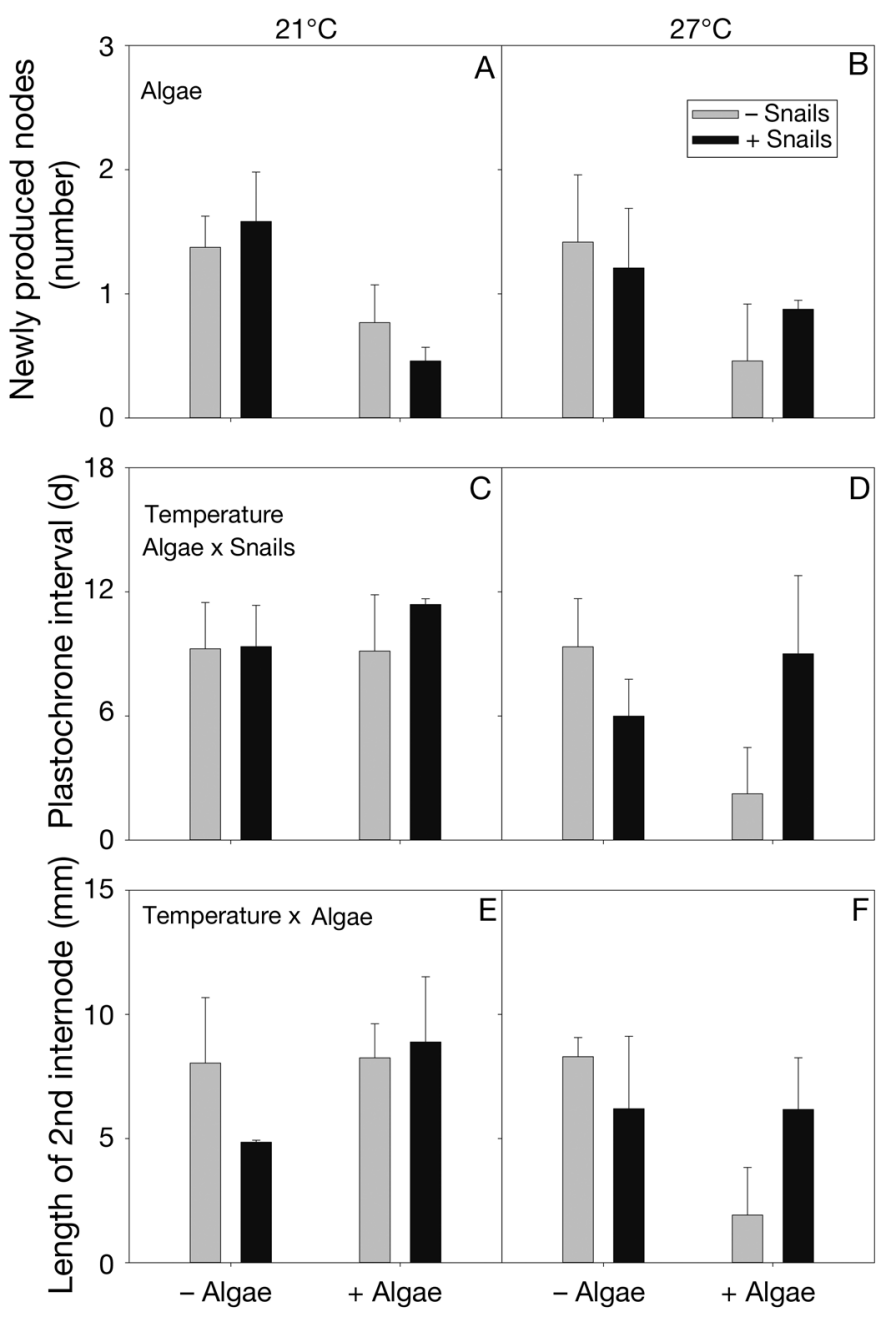

Fig. 4. Halophila ovalis. (A,B) Number of newly produced nodes, $(\mathrm{C}, \mathrm{D})$ leaf plastochrone interval and $(\mathrm{E}, \mathrm{F})$ length of the 2nd internode (mean $\pm \mathrm{SE}$ ) for shoots in aquaria with or without algae Chaetomorpha linum and snails Batillaria australis at $(\mathrm{A}, \mathrm{C}, \mathrm{E}) 21^{\circ} \mathrm{C}$ and $(\mathrm{B}, \mathrm{D}, \mathrm{F}) 27^{\circ} \mathrm{C}$. The factors or interactions named in the graph are those that caused significant differences

$(\mathrm{p}=0.373$; Table $\mathrm{S} 3$ in the supplement), while organic matter $(p>0.067)$ and chl $a(p>0.077)$ in the sediment (Table S4, Fig. S2 in the supplement) were not significantly affected by either treatment. However, in both temperature treatments, the sediments covered by combination of algae and snails had considerably more chl a than any of the other treatments (Fig. S2). The mean content of organic matter in the sediment was $0.43 \pm 0.04 \%$ dry wt ( $\mathrm{n}=8$ treatments) and the mean chl a content was $0.26 \pm 0.04 \mu \mathrm{g} \mathrm{cm}^{-3}$ ( $\mathrm{n}=8$ treatments).

The oxygen concentration in the water column depended on time of day, depth, temperature and 


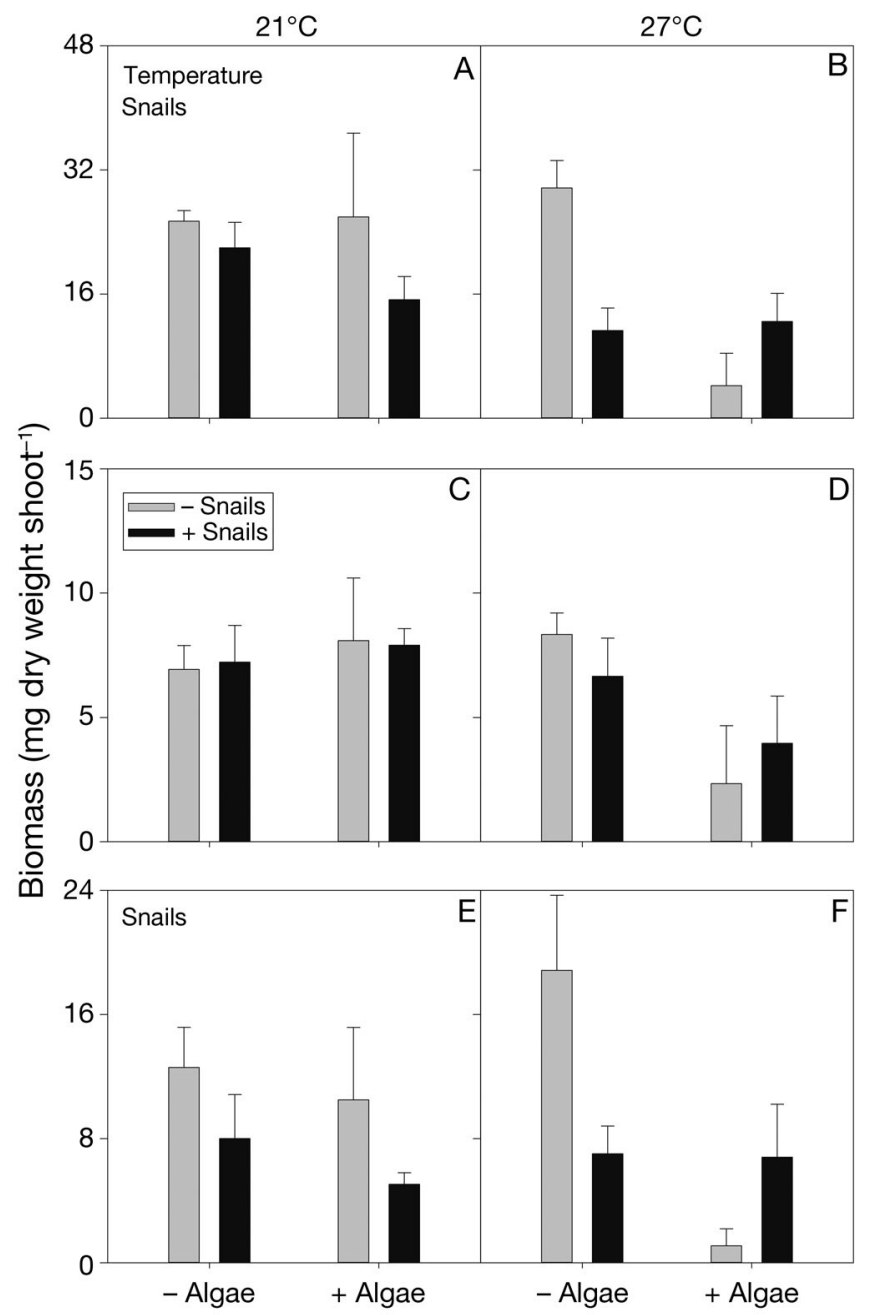

Fig. 5. Halophila ovalis. Biomass (mean $\pm \mathrm{SE}$ ) of $(\mathrm{A}, \mathrm{B})$ leaves, $(\mathrm{C}, \mathrm{D})$ rhizomes, and $(\mathrm{E}, \mathrm{F})$ roots for shoots in aquaria with or without algae Chaetomorpha linum and snails Batillaria australis at $(\mathrm{A}, \mathrm{C}, \mathrm{E}) 21^{\circ} \mathrm{C}$ and $(\mathrm{B}, \mathrm{D}, \mathrm{F}) 27^{\circ} \mathrm{C}$. The factors or interactions named in the graph are those that caused significant differences

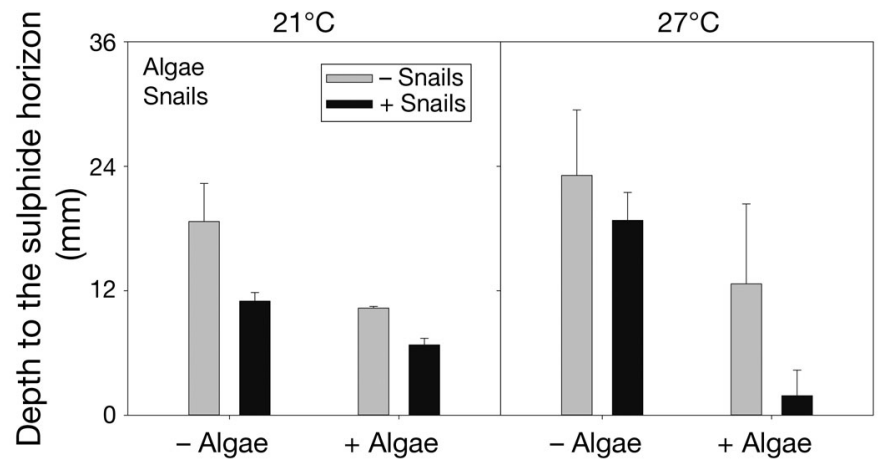

Fig. 6. Depth (mean $\pm \mathrm{SE}$ ) to sulphide horizon in aquaria with or without drift algae Chaetomorpha linum and snails Batillaria australis at (A) $21^{\circ} \mathrm{C}$ and (B) $27^{\circ} \mathrm{C}$. The factors or interactions named in the graph are those that caused significant differences
Table 1. PERMANOVA testing the effects of temperature (Te), drift algae (Al) and invasive snails (Sn) on the ecological performance of Halophila ovalis combined across all performance metrics. Significant values are in bold

\begin{tabular}{|c|c|c|c|c|c|}
\hline Source & df & MS & $\begin{array}{c}\text { Pseudo- } \\
F\end{array}$ & $\begin{array}{c}\mathrm{p} \\
\text { (perm) }\end{array}$ & $\begin{array}{c}\text { Components of } \\
\text { variation }(\%)\end{array}$ \\
\hline $\mathrm{Te}$ & 1 & 14.852 & 2.11 & 0.076 & 5.5 \\
\hline $\mathrm{Al}$ & 1 & 29.656 & 4.21 & 0.013 & 16.1 \\
\hline Sn & 1 & 18.666 & 2.65 & 0.038 & 8.3 \\
\hline $\mathrm{Te} \times \mathrm{Al}$ & 1 & 7.3451 & 1.04 & 0.365 & 0.4 \\
\hline $\mathrm{Te} \times \mathrm{Sn}$ & 1 & 5.4484 & 0.77 & 0.538 & 0 \\
\hline $\mathrm{Al} \times \mathrm{Sn}$ & 1 & 8.6351 & 1.23 & 0.268 & 2.3 \\
\hline $\mathrm{Te} \times \mathrm{Al} \times \mathrm{Sn}$ & 1 & 9.6601 & 1.37 & 0.205 & 7.4 \\
\hline Residual & 16 & 7.0460 & & & 60.0 \\
\hline
\end{tabular}

algae, but snails had no effect ( $p>0.325$; Fig. 7; Table S5 in the supplement). Oxygen concentrations were always lower at the bottom than at the surface $\left(\mathrm{SNK}_{\text {day, night: }}\right.$ bottom $<$ mid-water $=$ surface $)$, but the difference was much greater at night than during the day $\left(p_{\text {depth } \times \text { time }}=0.015 ;\right.$ Fig. 7$)$. The presence of drift algae caused lower oxygen levels at all depths

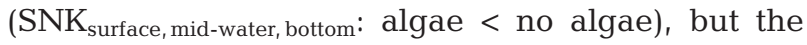
effects were much greater at the bottom than at any of the other depth strata $\left(p_{\text {depth } \times a l g a e}<0.0001\right.$; Fig. 7$)$ and these effects were further exaggerated at the high experimental temperature and at night $\left(p_{\text {temperature } \times \text { algae } \times \text { time }}=0.034 ;\right.$ Fig. 7$)$. Oxygen levels were always lower at $27^{\circ} \mathrm{C}$ compared to $21^{\circ} \mathrm{C}$ treatments $\left(\mathrm{SNK}_{\mathrm{day}}\right.$, night, algae, no algae: $\left.27<21^{\circ} \mathrm{C}\right)$, but day and night differed only when algae were present $\left(\mathrm{SNK}_{\text {no algae }}\right.$ night $=$ day, $\mathrm{SNK}_{\text {algae }}:$ night $<$ day $)$. There was a strong negative correlation between Halophila ovalis mortality rate and the mean oxygen concentration at the sediment surface at night $(\mathrm{r}=-0.65, \mathrm{p}=$ $0.0006, \mathrm{n}=24$ ), and there was a conspicuous increase in mortality rate below $6 \mathrm{mg} \mathrm{O}_{2} \mathrm{l}^{-1}$ (Fig. 8).

\section{DISCUSSION}

A critical step towards successfully managing and conserving ecologically important species such as seagrasses is understanding the effects of multiple, concurrent anthropogenic and environmental pressures. Here, we have documented that contemporary levels of drift algae and an invasive snail, and elevated temperature have significant negative effects on survival (increased mortality) and growth of a seagrass species that is ubiquitous in many warmtemperate to tropical estuaries and coastal areas 


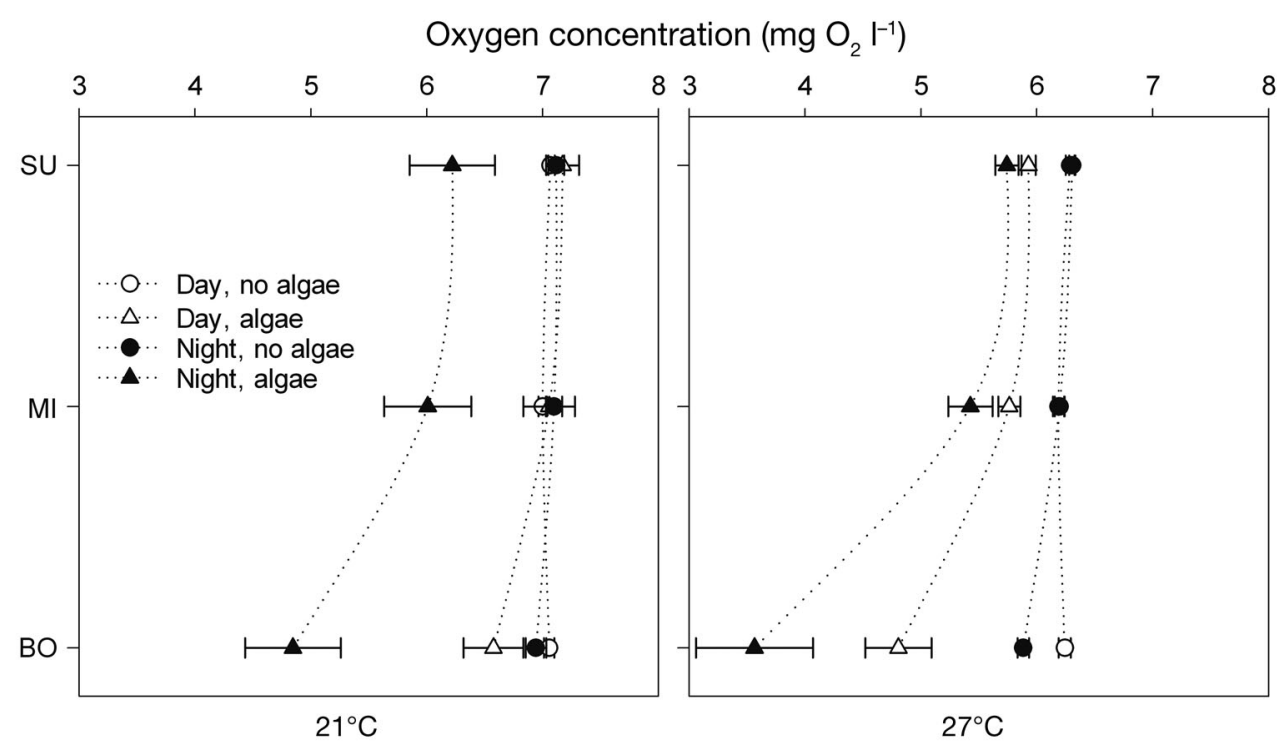

Fig. 7. Oxygen concentration (mean $\pm \mathrm{SE}$ ) at different depths, during day and night, in aquaria with and without drift algae Chaetomorpha linum at (A) $21^{\circ} \mathrm{C}$ and (B) $27^{\circ} \mathrm{C}$. As we had no expectation that snails would affect oxygen concentration in the water column, we pooled across snail treatments $(n=6$ treatments per data point, each the average of 4 measurements). SU: below the surface; MI: mid-water/within the algal mat; BO: bottom at the sediment surface

(Carruthers et al. 2007). Moreover, we documented that these effects predominantly were additive rather than synergistic or antagonistic.

\section{In situ patterns of drift algae, invasive snails and temperature}

\section{Drift algae}

Drift algae were ubiquitous within seagrass beds in the Swan River, and, as in other estuaries (cf. Kopecky \& Dunton 2006), were characterised by a clear summer peak, hinting at a seasonal pattern. The summer peak likely reflects concurrent increases in salinity, temperature and light levels during summer months, whereas spatial patchiness may be due to 'random' entanglement around leaf structures, counteracted by hydrodynamic forces from waves and tides (Biber 2007). Only 4 species contributed to $90 \%$ of the total algal biomass, but dominance by a few stress-tolerant and fastgrowing ephemeral species is common in estuaries (Valiela et al. 1997, McGlathery 2001). The survey also documented that the drift-algal load used in the experiment, although high, is ecologically relevant and can be found in patches in seagrass beds in the Swan River today. We did not quantify the stability of individual patches of drift algae, but the effects of drift algae will depend on their residence time in a specific location. The residence time largely depends on the flow velocities of currents at any given location and the roughness of the substrate (Biber 2007). Using tagging experiments, Astill \& Lavery (2001) showed that drift algae can persist for at least $3 \mathrm{wk}$ at low-energy sites in the Swan River, indicating that the duration of our impact experiment also has ecological relevance (cf. Holmer \& Nielsen 2007, Martinez-Lüscher \& Holmer 2010).

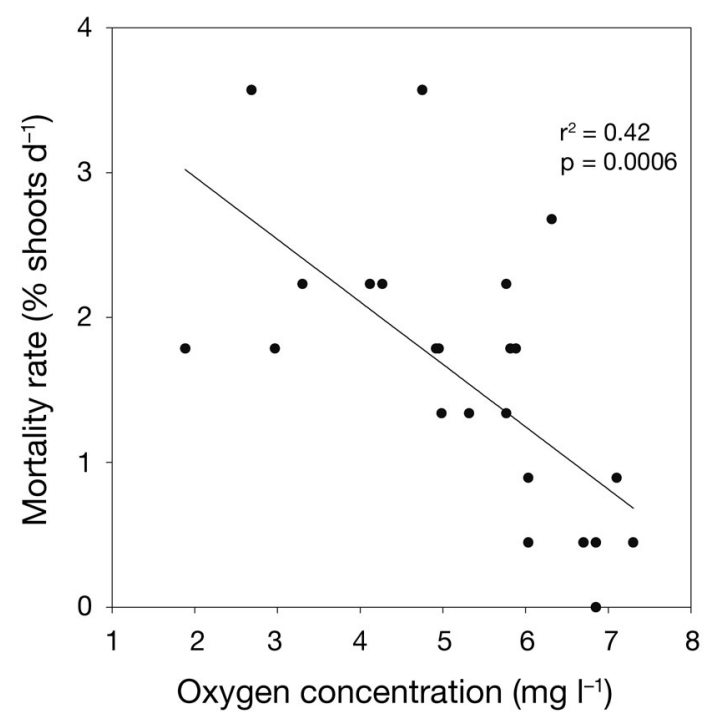

Fig. 8. Halophila ovalis. Relationship between mortality rate of shoots and oxygen concentration near the bottom at night. Data include all treatments ( $\mathrm{n}=24$ aquaria) 


\section{Snails}

The snail survey showed that Batillaria australis is very abundant in the Swan River, with an average of ca. 490 snails $\mathrm{m}^{-2}$ in seagrass beds. This mean value representing 3 sites is almost identical to what was reported from 10 seagrass beds in 2006 (Thomsen et al. 2010), suggesting a relatively uniform distribution of snails throughout the Swan River. High abundances of $B$. australis have also been reported from its native region in east Australian estuaries, with up to 2000 snails $\mathrm{m}^{-2}$ in seagrass beds near Sydney (Cummins 2005), perhaps suggesting that the carrying capacity for snails in the Swan River may not yet have been reached. High abundances of sibling species have been reported from New Zealand (Jones \& Marsden 2005), Japan (Kamimura \& Tsuchiya 2006) and in invaded estuaries on the US west coast (Byers 2000). This large snail and its morphologically similar sibling species are often found in high abundances in temperate and subtropical seagrass beds, probably due to a combination of high resistance to predators, gastropod competitors and environmental stress. Compared to in situ abundances, the density used in our experiment was relatively low. The impacts we have detected are therefore likely to be conservative estimates, and true impacts of $B$. australis on seagrass health in situ may potentially have been underestimated. Yet the density in the aquaria was similar to the density of $B$. australis in adjacent mudflats $\left(<100\right.$ snails $\left.\mathrm{m}^{-2}\right)$, making the results representative for the mudflat-seagrass interface.

\section{Temperature}

There was a substantial variation in temperature over the sampling period, as would be expected in an estuary in a Mediterranean-type climate, with some areas more prone to peak thermal stress than others. Importantly, our highest experimental temperature corresponded well with maximum summer temperatures measured in situ at the bottom where the seagrasses are found, again supporting the ecological relevance of our results.

\section{Experimental effects on ecological performance}

$$
\text { Effects of drift algae }
$$

The presence of drift algae was the stress factor that most often caused negative effects on Halophila ovalis performance, potentially by indirectly increasing sulphide concentrations in the sediment and hypoxia in the water column. Drift algae also explained most of the total variation in the experimental data. Several field experiments have documented negative impacts of drift algae on seagrasses (e.g. Holmquist 1997, Nelson \& Lee 2001, Cummins et al. 2004, Irlandi et al. 2004, Huntington \& Boyer 2008), most attributing adverse effects to competition for light. However, indirect effects associated with dark respiration by and decomposition of drift algae, causing hypoxia and increased sulphide in the water column and sediment pore water, can also cause rapid and severe stress on seagrasses (Krause-Jensen et al. 1999, Holmer \& Bondgaard 2001, Holmer \& Laursen 2002, Holmer et al. 2005, Holmer \& Nielsen 2007). These biogeochemical processes were observed in the present study, where the presence of drift algae raised the sulphide horizon in the sediment and reduced oxygen levels in the water column, ultimately resulting in a negative relationship between water-column oxygen and seagrass mortality. Similar negative effects of low oxygen levels have been reported for other seagrass species (Greve et al. 2003, Frederiksen \& Glud 2006), and seagrass mortality has previously been linked to low oxygen levels caused by drift algae (Holmer \& Nielsen 2007). Interestingly, the negative effects of drift algae were mainly observed on production responses, but with no detected effects on final biomass except a nearsignificant negative effect on leaf biomass. Major loss of biomass has been found in die-back areas, as the horizontal meristems soften, die back and eventually cause the loss of leaves (Carlson et al. 1994, Rask et al. 1999). Similar softening of $H$. ovalis rhizomes was found here, but the effect on shoot biomass may have been delayed by the low water movement in the aquaria failing to detach the leaves from the rhizomes (Holmer \& Bondgaard 2001, Mascaró et al. 2009). In contrast, Holmer et al. (2011) found a significant influence on the biomass per shoot of all plant compartments of $H$. ovalis. However, that experiment lasted 1 wk longer, potentially explaining the increased effect.

\section{Effects of snails}

Batillaria australis had negative effects on the biomass per shoot of both leaves and roots and a non-significant negative trend concerning rhizome biomass. $B$. australis is considered a deposit-feeder (Ewers $1967 a, b)$ that potentially can shift to filter-feeding (Kamimura \& Tsuchiya 2004, 2006). Direct grazing effects on Halophila ovalis are therefore unlikely. In- 
deed, most seagrass-gastropod studies document positive effects on seagrasses, as snails tend to consume epiphytes rather than the basiophyte (= cleaner effect; reviewed in Hughes et al. 2004). Thus, we are not aware of other experimental gastropod studies to have documented non-trophic negative effects on seagrass biomass. We hypothesise that a combination of direct 'uprooting' by bulldozing snails (1 to 2 shoots $\mathrm{d}^{-1}$ ) and indirect effects through deposition of organic matter increased sulphide stress and caused the negative effects on $H$. ovalis biomass. Similar negative effects associated with bioturbation at low seagrass density have been observed for a non-native crab in seagrass transplant experiments (Davis et al. 1998), and recent studies of other molluscs have shown that biodeposition from mussels (Vinther \& Holmer 2008, Vinther et al. 2008) and oysters (>150 ind. $\mathrm{m}^{-2}$; Booth \& Heck 2009) can have negative effects on seagrasses. As indicated in the experiments by Davis et al. (1998), it is possible that our effect was particularly strong due to the low planting density in the aquaria, mimicking the seagrass-mudflat interface, and it is likely that a denser and interconnected root-rhizome system (e.g. in the interior of healthy seagrass beds) may reduce the impacts of bioturbating organisms (Frederiksen et al. 2007). Interestingly, the same 2 mechanisms (snail movement and biodeposition) were proposed to explain positive effects of the invasive sibling species $B$. attramentaria on the invasive seagrass Zostera japonica (Wonham et al. 2005). However, that experiment was conducted in the interior of a seagrass bed, using a species with larger belowground structures and where uprooting is less likely. In addition, larger seagrass species can transport more oxygen from the water column to the rhizosphere, potentially benefiting from snail-induced nutrient enrichment. In short, more studies are needed to better understand when, where and how molluscs affect seagrass performance. We suggest it is particularly important to investigate snail movement patterns, density-dependent effects (Booth \& Heck 2009) and specific feeding strategies. Small-scale patterns of biodeposition and biogeochemistry, in concert with seagrass density dependent responses, e.g. the snails' ability to transfer oxygen and to resist sulphide toxicity, should also be investigated.

\section{Effects of temperature}

Negative effects of elevated temperature on Halophila ovalis performance were fewer than by drift algae and snails. The most severe effects were found in combination with drift algae. High temperature increased leaf loss, and, in the presence of drift algae, also reduced the length of the 2 nd internode. Increased mortality at temperatures near $30^{\circ} \mathrm{C}$ has been also observed by Holmer et al. (2011), whereas mortality only occurred at $37.5^{\circ} \mathrm{C}$ and higher for tropical $H$. ovalis, suggesting substantially higher temperature tolerance in tropical populations of this species (Ralph 1998). Similar to Zostera marina (Greve et al. 2003), H. ovalis may have higher respiratory oxygen demand at higher temperatures, reducing the oxygen available for plant cell activity and reducing the capacity of the plant to oxidise the sediment and therefore increasing the risk of sulphide intrusion (Borum et al. 2005). Drift-algal cover may further limit the oxygen supply, especially during the night, when the seagrass takes up oxygen from the water column. Only the treatment combining high temperature, drift algae and snails caused high sulphide concentrations. In contrast, other studies have shown increased sulphide concentrations in seagrass sediments during summer and linked them to sulphide intrusion (Frederiksen et al. 2007). Perhaps sulphide production in our setup was limited by the low organic content in the sediment. It is possible that sulphide stress can be stronger, and occur at lower temperatures, in situ where sediments have higher organic matter content. We also note that the temperature applied in the present study is similar to summer temperatures already experienced in the Swan River. It is therefore likely that higher temperatures in the future will reduce oxygen levels in the seagrass even further, and make seagrass beds more susceptible to die-offs.

\section{Interaction effects and conclusions}

Multiple anthropogenic stressors almost always cooccur (Breitburg et al. 1998, Crain et al. 2008, Halpern et al. 2008) and it is therefore essential to consider their combined effects. In the present study, relatively few interaction effects were detected on individual response variables, indicating that stress effects mainly were additive. Still, we found that the internode length (a complex growth response) decreased at high temperature but only in the presence of drift algae (Significant algae $\times$ Temperature interaction), and that the plastochrone interval (an inverse growth response) increased by snail addition, but again only in the presence of drift algae. Thus, for these 2 growth responses, one stressor (drift algae) compounded the influence of another stressor (snails or temperature). 
In a relatively similar experiment (Holmer et al. 2011), increased temperature generally accelerated the negative effects of the coarsely branched red macroalgae Gracilaria comosa on Halophila ovalis. Similar synergistic stress effects have been observed in other factorial seagrass experiments; Zostera marina was negatively affected by nutrient enrichment if also stressed by salinity (van Katwijk et al. 1999), Halodule wrightii and Thalassia testudinum were negatively affected by sulphide stress when combined with salinity and/ or temperature stress (Koch \& Erskine 2001, Koch et al. 2007) and T. testudinum was negatively affected by salinity stress if co-occurring with excessive amounts of nutrients (Kahn \& Durako 2006). However, Torquemada et al. (2005) found no synergistic effects between salinity stress, temperature and $\mathrm{pH}$ on Halophila johnsonii performance. Nevertheless, the few seagrass studies that have included factorial-stress combinations indicate that adverse synergistic effects can be important and thereby provide a crucial warning that the health and status of future seagrass beds should be interpreted in a context of co-occurring stressors. In this context, we have here documented that additive and synergistic effects of climate change, eutrophication and invasive species are likely to negatively impact seagrass beds in the Swan River if either of these factors is increased in the future. As increasing temperatures, drift algae and invasive snails are contemporary threats for many other estuaries, these findings are likely to be widely applicable.

Acknowledgements. The research in this paper was supported by grant 95-306-13697 from the Siemens foundation to H.H., grants 272-05-0408 and 272-07-0031 from the Danish National Science Research Foundation to M.H., Australian Research Council Discovery Grant (DP0555929) and Future Fellowship (FT110100174) to T.W. and grants from the Swan River Trust (SCRIP) and Edith Cowan University to T.W. and M.S.T.; M.S.T. was also supported by the Danish National Science Research Foundation and the Portuguese Fundação para a Ciência e a Tecnologia (FCT) and Fondo Europeo de Desarrollo Regional (FEDER) through project INVASEA (PTDC/MAR/098069/2008).

\section{LITERATURE CITED}

Armstrong J, Armstrong W (2005) Rice: sulfide-induced barriers to root radial oxygen loss, $\mathrm{Fe}^{2+}$ and water uptake, and lateral root emergence. Ann Bot 96:625-638

Astill H, Lavery PS (2001) The dynamics of unattached benthic macroalgal accumulations in the Swan-Canning Estuary. Hydrol Process 15:2387-2399

Biber PD (2007) Transport and persistence of drifting macroalgae (Rhodophyta) are strongly influenced by flow velocity and substratum complexity in tropical seagrass habitats. Mar Ecol Prog Ser 343:115-122
Biebl R, McRoy CP (1971) Plasmatic resistance and rate of respiration and photosynthesis of Zostera marina at different salinities and temperatures. Mar Biol 8:48-56

> Booth DM, Heck KL (2009) Effects of the American oyster Crassostrea virginica on growth rates of the seagrass Halodule wrightii. Mar Ecol Prog Ser 389:117-126

> Borum J, Pedersen O, Greve TM, Frankovich TA, Zieman JC, Fourqurean JW, Madden CJ (2005) The potential role of plant oxygen and sulphide dynamics in die-off events of the tropical seagrass, Thalassia testudinum. J Ecol 93:148-158

Brearley A (2005) Ernest Hodgkin's Swanland. Estuaries and coastal lagoons in South Western Australia. University of Western Australia Press, Perth

Breitburg D, Baxter J, Hatfield C, Howarth R, Jones C, Lovett G (1998) Understanding effects of multiple stressors: ideas and challenges. In: Pace M, Groffman P (eds) Successes, limitations, and frontiers in ecosystem science. Springer, New York, NY, p 416-431

> Byers JE (2000) Differential susceptibility to hypoxia aids estuarine invasion. Mar Ecol Prog Ser 203:123-132

Carlson PR, Yarbro LA, Barber TR (1994) Relationship of sediment sulfide to mortality of Thalassia testudinum in Florida Bay. Bull Mar Sci 54:733-746

> Carruthers TJB, Dennison WC, Kendrick GA, Waycott M, Walker DI, Cambridge ML (2007) Seagrasses of southwest Australia: a conceptual synthesis of the world's most diverse and extensive seagrass meadows. J Exp Mar Biol Ecol 350:21-45

Clarke KR, Gorley RN (2006) Primer v6: user manual/tutorial. PRIMER-E, Plymouth

Crain CM, Kroeker K, Halpern BS (2008) Interactive and cumulative effects of multiple human stressors in marine systems. Ecol Lett 11:1304-1315

Cummins SP (2005) Behaviour of the snail, Batillaria australis, in meadows of seagrass. PhD thesis, University of Sydney

$>$ Cummins SP, Roberts DE, Zimmerman KD (2004) Effects of the green macroalga Enteromorpha intestinalis on macrobenthic and seagrass assemblages in a shallow coastal estuary. Mar Ecol Prog Ser 266:77-87

> Davis RC, Short FT, Burdick DM (1998) Quantifying the effects of green crab damage to eelgrass transplants. Restor Ecol 6:297-302

> Duarte CM, Marba N, Agawin N, Cebrian J and others (1994) Reconstruction of seagrass dynamics: age determinations and associated tools for the seagrass ecologist. Mar Ecol Prog Ser 107:195-209

Ewers W (1967a) Geographic variation in the snail Velacumantus australis (Gastropoda: Potamididiae). Aust J Zool 15:1163-1171

- Ewers W (1967b) The distribution of Velacumantus australis (Gastropoda: Potamididae). Aust J Zool 15: 581-591

- Frederiksen MS, Glud RN (2006) Oxygen dynamics in the rhizosphere of Zostera marina: a two-dimensional planar optode study. Limnol Oceanogr 51:1072-1083

> Frederiksen MS, Holmer M, Díaz-Almela E, Marba N, Duarte CM (2007) Sulfide invasion in the seagrass Posidonia oceanica at Mediterranean fish farms: assessment using stable sulfur isotopes. Mar Ecol Prog Ser 345: 93-104

Greve TM, Borum J, Pedersen O (2003) Meristematic oxygen variability in eelgrass (Zostera marina). Limnol Oceanogr 48:210-216 
Halpern BS, Walbridge S, Selkoe KA, Kappel CV and others (2008) A global map of human impact on marine ecosystems. Science 319:948-952

Hauxwell J, Cebrian J, Valiela I (2003) Eelgrass Zostera marina loss in temperate estuaries: relationship to landderived nitrogen loads and effect of light limitation imposed by algae. Mar Ecol Prog Ser 247:59-73

> Hillman K, McComb AJ, Walker DI (1995) The distribution, biomass and primary production of the seagrass Halophila ovalis in the Swan/Canning Estuary, Western Australia. Aquat Bot 51:1-54

> Holmer M, Bondgaard EJ (2001) Photosynthetic and growth response of eelgrass to low oxygen and high sulfide concentrations during hypoxic events. Aquat Bot 70:29-38

> Holmer M, Laursen L (2002) Effect of shading of Zostera marina (eelgrass) on sulfur cycling in sediments with contrasting organic matter and sulfide pools. J Exp Mar Biol Ecol 270:25-37

> Holmer M, Nielsen RM (2007) Effects of filamentous algal mats on sulfide invasion in eelgrass (Zostera marina). J Exp Mar Biol Ecol 353:245-252

> Holmer M, Frederiksen MS, Mollegaard H (2005) Sulfur accumulation in eelgrass (Zostera marina) and effect of sulfur on eelgrass growth. Aquat Bot 81:367-379

> Holmer M, Wirachwong P, Thomsen MS (2011) Negative effects of stress-resistant drift algae and high temperature on a small ephemeral seagrass species. Mar Biol 158:297-309

Holmquist JG (1997) Disturbance and gap formation in a marine benthic mosaic: influence of shifting macroalgal patches on seagrass structure and mobile invertebrates. Mar Ecol Prog Ser 158:121-130

Hughes RA, Bando KJ, Rodriguez LF, Williams SL (2004) Relative effects of grazers and nutrients on seagrasses: a meta-analysis approach. Mar Ecol Prog Ser 282:87-99

> Huntington BE, Boyer KE (2008) Effects of red macroalgal (Gracilariopsis sp.) abundance on eelgrass Zostera marina in Tomales Bay, California, USA. Mar Ecol Prog Ser 367:133-142

> Irlandi EA, Orlando BA, Biber PD (2004) Drift algae-epiphyte-seagrass interactions in a subtropical Thalassia testudinum meadow. Mar Ecol Prog Ser 279:81-91

Jones MB, Marsden ID (2005) Life in the estuary. Canterberry University Press, Christchurch

Kahn AE, Durako MJ (2006) Thalassia testudinum seedling responses to changes in salinity and nitrogen levels. J Exp Mar Biol Ecol 335:1-12

Kamimura S, Tsuchiya M (2004) The effect of feeding behavior of the gastropods Batillaria zonalis and Cerithideopsilla cingulata on their ambient environment. Mar Biol 144:705-712

Kamimura S, Tsuchiya M (2006) Effects of opportunistic feeding by the intertidal gastropods Batillaria zonalis and B. flectosiphonata on material flux on a tidal flat. Mar Ecol Prog Ser 318:203-211

- Kilminster KL, Walker DI, Thompson PA, Raven JA (2008) Changes in growth, internode distance and nutrient concentrations of the seagrass Halophila ovalis with exposure to sediment sulphide. Mar Ecol Prog Ser 361: 83-91

- Koch MS, Erskine JM (2001) Sulfide as a phytotoxin to the tropical seagrass Thalassia testudinum: interactions with light, salinity and temperature. J Exp Mar Biol Ecol 266: 81-95

Koch MS, Schopmeyer S, Kyhn-Hansen C, Madden CJ
(2007) Synergistic effects of high temperature and sulfide on tropical seagrass. J Exp Mar Biol Ecol 341:91-101

Kopecky AL, Dunton KH (2006) Variability in drift macroalgal abundance in relation to biotic and abiotic factors in two seagrass dominated estuaries in the western Gulf of Mexico. Estuar Coasts 29:617-629

> Krause-Jensen D, Christensen PB, Rysgaard S (1999) Oxygen and nutrient dynamics within mats of the filamentous macroalga Chaetomorpha linum. Estuaries 22:31-38

> Lotze HK, Lenihan HS, Bourque BJ, Bradbury RH and others (2006) Depletion, degradation, and recovery potential of estuaries and coastal seas. Science 312:1806-1809

Martinez-Lüscher J, Holmer M (2010) Potential effects of the invasive species Gracilaria vermiculophylla on Zostera marina metabolism and survival. Mar Environ Res 69: 345-349

> Mascaró O, Valdemarsen T, Holmer M, Perez M, Romero J (2009) Experimental manipulation of sediment organic content and water column aeration reduces Zostera marina (eelgrass) growth and survival. J Exp Mar Biol Ecol 373:26-34

- McGlathery KJ (2001) Macroalgal blooms contribute to the decline of seagrass in nutrient-enriched coastal waters. J Phycol 37:453-456

Nelson TA, Lee A (2001) A manipulative experiment demonstrates that blooms of the macroalga Ulvaria obscura can reduce eelgrass shoot density. Aquat Bot 71: 149-154

Nielsen SL, Sand-Jensen K, Borum J, Geertz-Hansen O (2002) Depth colonization of eelgrass (Zostera marina) and macroalgae as determined by water transparency in Danish coastal waters. Estuaries 25:1025-1032

> Orth RJ, Carruthers TJB, Dennison WC, Duarte CM and others (2006) A global crisis for seagrass ecosystems. Bioscience 56:987-996

> Pearce A, Feng M (2007) Observations of warming on the Western Australian continental shelf. Mar Freshw Res 58:914-920

> Pedersen O, Binzer T, Borum J (2004) Sulphide intrusion in eelgrass (Zostera marina L.). Plant Cell Environ 27: 595-602

> Pedersen MF, Staehr PA, Wernberg T, Thomsen MS (2005) Biomass dynamics of exotic Sargassum muticum and native Halidrys siliquosa in Limfjorden, Denmarkimplications of species replacements on turnover rates. Aquat Bot 83:31-47

> Pischedda L, Poggiale JC, Cuny P, Gilbert F (2008) Imaging oxygen distribution in marine sediments. The importance of bioturbation and sediment heterogeneity. Acta Biotheor 56:123-135

Poloczanska ES, Babcock RC, Butler A, Hobday A and others (2007) Climate change and Australian marine life. Oceanogr Mar Biol Annu Rev 45:407-478

Ralph PJ (1998) Photosynthetic response of laboratory-cultured Halophila ovalis to thermal stress. Mar Ecol Prog Ser 171:123-130

Rask N, Pedersen SE, Jensen MH (1999) Response to lowered nutrient discharges in the coastal waters around the island of Funen, Denmark. Hydrobiologia 393:69-81

Raven JA, Scrimgeour CM (1997) The influence of anoxia on plants of saline habitats with special reference to the sulphur cycle. Ann Bot 79(Suppl 1):79-86

Sage M (2002) GMAV for Windows. Instruction manual. Centre for Research on Ecological Impacts of Coastal Cities, University of Sydney, Sydney 
Sand-Jensen K, Pedersen O, Binzer T, Borum J (2005) Contrasting oxygen dynamics in the freshwater isoetid Lobelia dortmanna and the marine seagrass Zostera marina. Ann Bot 96:613-623

Short F, Duarte C (2001) Methods for the measurement of seagrass growth and production. In: Short FT (ed) Global seagrass research methods. Elsevier Science, Amsterdam, p 155-182

Short FT, Neckles HA (1999) The effects of global climate change on seagrasses. Aquat Bot 63:169-196

Stæhr PA, Wernberg T (2009) Physiological responses of Ecklonia radiata (Laminariales) to a latitudinal gradient in ocean temperature. J Phycol 45:91-99

Thamdrup B, Hansen JW, Jørgensen BB (1998) Temperature dependence of aerobic respiration in a coastal sediment. FEMS Microbiol Ecol 25:189-200

Thomsen MS (2010) Experimental evidence for positive effects of invasive seaweed on native invertebrates via habitat-formation in a seagrass bed. Aquat Invasions 5: 341-346

Thomsen MS, Wernberg T, Tuya F, Silliman BR (2009) Evidence for impacts of nonindigenous macroalgae: a metaanalysis of experimental field studies. J Phycol 45: 812-819

Thomsen MS, Wernberg T, Tuya F, Silliman BR (2010) Ecological performance and possible origin of a ubiquitous but under-studied gastropod. Estuar Coast Shelf Sci 87: 501-509

Thomsen MS, Wernberg T, Olden JD, Griffin JN, Silliman BR (2011) A framework to study the context-dependent

Editorial responsibility: Hans-Heinrich Janssen, Oldendorf/Luhe, Germany impacts of marine invasions. J Exp Mar Biol Ecol 400: 322-327

Torquemada YF, Durako MJ, Lizaso JLS (2005) Effects of salinity and possible interactions with temperature and $\mathrm{pH}$ on growth and photosynthesis of Halophila johnsonii Eiseman. Mar Biol 148:251-260

> Valiela I, McClelland J, Hauxwell J, Behr PJ, Hersh D, Foreman K (1997) Macroalgal blooms in shallow estuaries: controls and ecophysiological and ecosystem consequences. Limnol Oceanogr 42:1105-1118

van Katwijk MM, Schmitz GHW, Gasseling AP, van Avesaath PH (1999) Effects of salinity and nutrient load and their interaction on Zostera marina. Mar Ecol Prog Ser 190:155-165

> Vinther HF, Holmer M (2008) Experimental test of biodeposition and ammonium excretion from blue mussels (Mytilus edulis) on eelgrass (Zostera marina) performance. J Exp Mar Biol Ecol 364:72-79

Vinther HF, Laursen JS, Holmer M (2008) Negative effects of blue mussel (Mytilus edulis) presence in eelgrass (Zostera marina) beds in Flensborg fjord, Denmark. Estuar Coast Shelf Sci 77:91-103

> Williams SL (2007) Introduced species in seagrass ecosystems: status and concerns. J Exp Mar Biol Ecol 350:89-110

> Williams SL, Smith JE (2007) A global review of the distribution, taxonomy, and impacts of introduced seaweeds. Annu Rev Ecol Evol Syst 38:327-359

> Wonham MJ, O'Connor M, Harley CDG (2005) Positive effects of a dominant invader on introduced and native mudflat species. Mar Ecol Prog Ser 289:109-116

Submitted: June 6, 2011; Accepted: December 14, 2011 Proofs received from author(s): March 11, 2012 